\title{
KLINIKINIS ATVEJIS: PPP SINDROMAS
}

\author{
Ilma Vilčinskaitė ${ }^{1}$, Gintarė Srèbaliūtė², Martynas Garčauskis ${ }^{2}$ \\ ${ }^{1}$ Klaipédos universitetiné ligonine, ${ }^{2}$ Lietuvos sveikatos mokslu universiteto Medicinos fakultetas
}

Raktažodžiai: PPP sindromas, pankreatitas, panikulitas, poliartritas, kaulų čiulpų nekrozè, magnetinio rezonanso tomografija.

\begin{abstract}
Santrauka
PPP sindromas - pankreatito ir jo sukeltu ekstrapankreatinių simptomų kompleksas, pasireiškiantis panikulitu, poliartritu ir kaulų čiulpų nekroze. Pristatomas klinikinis atvejis, kai pacientui, sergančiam ūminiu pankreatitu, ligos eigoje atsirado retai pasitaikantis ir diagnozuojamas ekstrapankreatinių simptomų kompleksas: odos bėrimas, lydimas čiurnų, riešo, kelio sąnarių uždegimo su kaulų čiulpų nekroze. Ši patologija patvirtinta magnetinio rezonanso tomografijos tyrimu. Taikant adekvatų ūmaus pankreatito bei jo komplikacijų (fistulès, kasos pseudocistos) chirurgini gydymą stebèta teigiama pakitimų (bèrimų, kaulų ir sąnarių pažeidimų, laboratorinių tyrimų) dinamika. Taikant adekvatų ūmaus pankreatito gydymą stebėta teigiama pakitimų (bẻrimų, kaulų ir sąnarių pažeidimų) dinamika.
\end{abstract}

\section{Ivadas}

Ūminis pankreatitas apibūdinamas kaip ūmus uždegiminis ir nekrozinis kasos pažeidimas, histologiškai pasireiškiantis acininių ląstelių destrukcija [1]. Ši patologija dažniausiai pasireiškia dèl obstrukcijos, kurią sukelia tulžies akmenys $(36,9-50 \%)$, taip pat gali būti idiopatinès kilmès (20-34\%) ir atsiradusi dèl alkoholio vartojimo (22\%). Retesnès priežastys - hiperlipidemija (10,1\%), pilvo trauma $(1,5 \%)$, prasta mityba $(0,3 \%)[2,3]$. Ūminio pankreatito pasireiškimo dažnis siekia 13-45 atveju 100000 gyventojų per metus, vyrams jis pasitaiko $10-30 \%$ dažniau nei moterims $[2,4]$. Alkoholio sukeltas ūminis pankreatitas dažniausiai pasireiškia vidutinio amžiaus (34-54 metų) vyrams [2,3].

Retais atvejais pankreatito kliniką gali lydèti panikulitas ir artritas, kurie gali pasireikšti kartu arba atskirai [5]. Pankreatinès kilmès artritas būna rečiau nei panikulitas. Pankreatito ir jo sukeltų ekstrapankreatinių simptomų kompleksas, pasireiškiantis panikulitu, poliartritu ir kaulų čiulpų nekroze, yra vadinamas PPP sindromu [6]. Tai labai reta kasos pažeidimo komplikacija, būna $0,3-3 \%$ pacientų, sergančių ùminiu, lètiniu pankreatitu ar kasos vèžiu $[7,8] .60 \%$ atvejų PPP sindromą sukelia ūminis pankreatitas. Sindromas dažniau pasireiškia vartojantiems alkoholị, jaunesniems nei 50 metų amžiaus pacientams ir dvigubai dažniau vyrams nei moterims $[6,9]$. Šiuo metu literatūroje aprašyta mažiau nei 100 šio sindromo atvejų [10].

Tiksli aptariamų pažeidimų patogenezė nẻra žinoma, tačiau manoma, jog ekstrapankreatines komplikacijas (panikulitą ir poliartritą) sukelia ị sisteminę kraujotaką patekę kasos fermentai, ypač lipazė $[6,10]$. Fermentai sukelia sisteminę riebalinio audinio nekrozę, dažniausiai pažeidžiančią poodinį riebalinį audinị, sinoviją ir kaulų čiulpus, formuojasi riebaliniai embolai. Pažeidimo procesą gali lydèti kremzliu nekrozè, kauliniai infarktai, ịvykti patologiniai lūžiai. Manoma, kad artritą gali sukelti ir laisvosios riebalų rūgštys, patekusios ị sąnarị iš kaulų čiulpuose kasos fermentų suskaidytų trigliceridų $[6,8,11]$.

PPP sindromo atveju panikulitas kliniškai pasireiškia kaip rausvi $0,5-5 \mathrm{~cm}$ dydžio mazgeliai ant odos bet kurioje kūno vietoje. Jie primena bėrimą, būdingą mazginei eritemai [9]. Histologiškai matoma poodinio riebalinio audinio nekrozé su aplinkinių audinių uždegimine reakcija bei vaiduokliškais (angl. ghost-like) adipocitais - bebranduolès ląstelès su sustorejjusia sienele [6]. Retkarčiais gali susidaryti sterilūs pūliniai ar pratrūksta bėrimų mazgeliai, iš kurių gali skirtis tirštas, pūlius primenantis skystis, turintis daug lipidų [6,9].

Kaulų pažeidimas su sąnarių skausmu ịprastai pasireiškia 3-4 savaitę po ūmaus kasos pažeidimo [11]. Sąnarių pažeidimas $88 \%$ atvejų išsivysto ị simetrinị ar asimetrinį poliartritą, $8 \%$ - i oligoartritą, $4 \%$ - i monoartritą. Dažniausiai pažeidžiami čiurnų, kelių, riešų bei metakarpofalanginiai sąnariai, rečiau - proksimaliniai ranku ir distaliniai interfalanginiai alkūnių bei smulkieji pèdų sąnariai $[5,9,10]$. Pažeistiems sąnariams būdingas skausmingumas, paraudimas, patinimas, riboti, skausmingi judesiai.

Pažeisto sąnario punktatas būna gelsvas, tirštesnès kon- 
sistencijos, sterilus, jame randama daug leukocitų, lipidų ar jų kristalų $[6,9,12]$. Rentgenologinių tyrimų metu pažeistuose kauluose matomi daugybiniai osteolitiniai židiniai su smulkiais pašviesejjimo (angl. moth-eaten) židiniais, periostitas, sumažèjęs sąnarinis tarpas. Minkštujų audinių pažeidimui diagnozuoti jautresnis yra magnetinio rezonanso tomografijos tyrimas, gali būti stebima kaulų čiulpų nekrozè ir edema, sinovijos uždegimas, paraartikulinių audinių edema $[5,6,8-11,13]$.

Tikslus pankreatito sukelto panikulito, artrito bei kaulu čiulpų nekrozės gydymas nèra aiškus. Dažniausiai šie pažeidimai regresuoja ir išnyksta gydant pirminę ligą - pankreatitą, tačiau kartais artrito eiga gali nepriklaustyti nuo pirminès ligos ir toliau progresuoti kasos fermentams atsistačius ị normos ribas [5,9]. Turètų būti gydomos ir kitos pankreatito komplikacijos - fistulès, pseudocistos, dèl kuriụ ị sisteminę kraujotaką kartais gali patekti didelis kiekis kasos fermentu $[6,9]$. Pankreatito sukeltas poliartritas dažniausiai gydomas NVNU ir gliukokortikoidais, tačiau nèra įrodymų, jog šie vaistai gerintų ligos prognozę ar trumpintų ligos eigą, todèl šis gydymo metodas laikomas simptominiu $[5,6,9]$.

Maždaug pusei pacientų radiologiškai stebima agresyvi artrito eiga be atsako ị medikamentini gydymą, vèliau pereinanti ị lètinị procesą [9]. Ketvirtadalis pacientų, kuriems pasireiškė PPP sindromas, miršta $[9,10]$.

Darbo tikslas: pristatyti reto PPP sindromo sékmingo gydymo klinikini atveji.

\section{Klinikinis atvejis}

34 metų vyras stacionarizuotas ị Klaipèdos universitetinès ligoninès gastroenterologijos skyrių dèl skausmų epigastriumo srityje ir stiprių, progresuojančių abiejų čiurnų, kairiojo riešo bei kairiojo kelio sąnarių skausmų, tinimų ir paraudimo.

Pacientas prieš tai gydytas rajono ligoninėje, kur jam diagnozuotas ūminis pankreatitas, tačiau teigiamo atsako i gydymą negauta. Gydymo eigoje atsirado kairiojo riešo, vèliau - čiurnų ir kelio sąnarių skausmai. Prieš patekdamas ị ligoninę, pacientas 2-3 savaites gausiai vartojo alkoholi. Anksčiau jokiomis ligomis nesirgęs.

Apžiūros metu nustatyta, kad pacientas nekarščiuoja, pulsas $80 \mathrm{k}$./min., AKS - 100/88 mm Hg. Čiuopiant pilvas skausmingas visame plote, bet be pilvaplèvès dirginimo reiškinių. Abiejų kelių ir blauzdų srityje matomi nedideli, iki 1 $\mathrm{cm}$, rausvos spalvos ir kietos konsistencijos bèrimai iškiliu paviršiumi. Abiejų čiurnų, kairiųų riešo ir kelio sąnariuose pastebètas ryškus patinimas, skausmingi sumažejusios amplitudès judesiai. Minèti simptomai labiausiai išryškejję kairiojo kelio sąnaryje. Atlikus kraujo tyrimus, nustatyta anemija $(\mathrm{Hb}-99 \mathrm{~g} / \mathrm{l}, \mathrm{CRB}-178,24 \mathrm{mg} / \mathrm{l})$ ir ženkliai padidejusi pankreatinès amilazès koncentracija kraujyje - 2559 U/l. Pilvo organų KT tyrimai parodè, kad kasa fragmentuota su peripankreatinių audinių infiltracija. Pacientui diagnozuotas ūmus pankreatitas, paskirtas konservatyvus gydymas. Dèl bérimų ir poliartrito požymių sergantysis konsultuotas reumatologo. İtarta reaktyvi artropatija.

Ultragarsinio kairiojo kelio sąnario tyrimo metu rasta edema paraartikuliniuose audiniuose ir neskaidraus skysčio sąnario bursose bei kišenèse. Punktuoto kelio sąnario skystyje bakterijų augimas neaptiktas. Atlikti tyrimai ir ekskliuduotos kitos galimos artrito priežastys: reumatoidinis artritas, podagra, lytiškai plintančios ligos (U. urealyticus M. hominis, C. trachomatis). Atlikus imunologinius tyrimus, atmesta ŽIV, hepatitai B ir C.

Atlikus kairiojo kelio MRT tyrimą rasti daugybiniai kaulų čiulpų infarktai su aplinkine kaulų čiulpų edema, padidejjęs sąnarinio skysčio kiekis, sustorejusi ir kontrastinę medžiagą kaupianti sinovija, Beikerio cista. Vertinant atliktus radiologinius ir laboratorinius tyrimus, kliniką, pacientui diagnozuotas pankreatito sukeltas panikulitas su poliartritu ir kaulų čiulpų nekroze. Paskirtas gydymas prednizolonu, NVNU.

Tęsiant gydymą išliko padidejjusi pankreatinès amilazès koncentracija kraujyje, todèl atlikta pilvo srities MRT. Lyginant su anksčiau atliktu KT tyrimu, pastebèta teigiama dinamika - ūmaus pankreatito požymiai regresavę, tačiau už kasos galvos rasta pseudocista, turinti ryšį su pagrindiniu kasos lataku, - tikriausiai fistulè. Konsultuotasi su abdominaliniu chirurgu, kuris rekomendavo tęsti konservatyvų gydymą.

Pacientas toliau gydytas prednizolonu, NVNU, užtikrinta gausi pakankama infuzoterapija. Gydant pilvo skausmai ir bėrimai išnyko, regresavo sąnarių patinimas bei paraudimas, išliko tik nežymus skausmingumas. Sumažějo CRB ir pankreatinès amilazès koncentracija kraujyje. Po teigiamo atsako i gydymą pacientas buvo pasiųstas tolimesniam gydymui i rajono ligoninę. Rekomenduota chirurgo konsultacija dèl operacinio kasos fistulès gydymo. Po ménesio pacientas stacionarizuojamas ị KUL vidaus ligų diagnostikos skyrių dèl vèl progresuojančių kelių, čiurnų, alkūnių sanarių skausmų, patinimų. Pakartojus tyrimus nustatyta padidejjusi lipazè iki 8888U/L. Pilvo organų MRT: retroperitoninè retropankreatinè pseudocista, panašu jog turinti ryši (fistulę) su kasos lataku, dinamikoje didejjanti. Turinti du apribotus skysčio segmentus, susijusius su apatine tuščiaja vena. İtariama fistulè ị venos spindį. Pacientas operuotas: atverta kasos pseudocista, rasta apatinès tuščiosios venos fistulè, kuri užsiūta. Po operacijos sumažejo sanarių skausmai ir patinimai, lipazė sumažejo iki 8U/L. Pacientas išrašytas rekomenduojant kasos pakaitinę fermentoterapiją ir tęsti NVNU. 


\section{Išvados}

PPP sindromas - itin reta komplikacija, pasireiškianti pacientams, sergantiems destrukcinio pobūdžio kasos ligomis. Daugiau kaip pusè sindromo atvejų sukeliami ūmaus pankreatito. Šis sindromas diagnozuojamas remiantis klinikiniais simptomais ir radiologiniais tyrimais, atmetus kitas galimas bėrimų bei artrito priežastis. Aprašomu klinikiniu atveju pacientui, sergančiam alkoholio sukeltu ūminiu pankreatitu, pasireiškè PPP sindromas su tipiškais bėimais odoje, poliartritu ir MRT patvirtinta diagnoze, kuriai būdingas sąnarių bei kaulų pažeidimas. Konservatyvus pankreatito gydymo būdas bei simptominis gydymas NVNU ir gliukokortikoidais nebuvo pakankamai efektyvus. Chirurginis kasos pseudocistos bei fistulès ị apatinę tuščiają veną gydymas žymiai pagerino paciento būklę, laboratoriniai rodikliai normalizavosi.

\section{Literatūra}

1. Garber A, Frakes C, Arora Z, Chahal P. Mechanisms and management of acute pancreatitis. Gastroenterol Res Pract 2018 Mar 15;6218798. https://doi.org/10.1155/2018/6218798

2. Shah AP, Mourad MM, Bramhall SR. Acute pancreatitis: current perspectives on diagnosis and management. J Inflamm Res 2018 Mar 9;11:77-85. https://doi.org/10.2147/JIR.S135751

3. Roberts SE, Akbari A, Thorne K, Atkinson M, Evans PA. The incidence of acute pancreatitis: impact of social deprivation, alcohol consumption, seasonal and demographic factors. Aliment Pharmacol Ther 2013;38(5):539-548.

https://doi.org/10.1111/apt.12408

4. Yadav D, Lowenfels AB. The epidemiology of pancreatitis and pancreatic cancer. Gastroenterology 2013;144(6):1252-1261. https://doi.org/10.1053/j.gastro.2013.01.068

5. Kocabas H, Melikoglu, MA, Sezer I, Gurbuz U, Kacar C, Butun B. Acute pancreatitis presenting with polyarthritis and intraosseous fat necrosis: a case report. Archives of Rheumatology 2010;25(4):221-224.

https://doi.org/10.5152/tjr.2010.33

6. Dieker W, Derer J, Henzler T. et al. Pancreatitis, panniculitis and polyarthritis (PPP) syndrome caused by post-pancreatitis pseudocyst with mesenteric fistula. Diagnosis and successful surgical treatment. Case report and review of literature. Int J Surg Case Rep 2017;31:170-175. https://doi.org/10.1016/j.ijscr.2017.01.037

7. Karasick D, Schweitzer ME. Case 4: intraosseous fat necrosis associated with pancreatitis. Radiology 1998 Nov;209(2):521524. https://doi.org/10.1148/radiology.209.2.9807583

8. Vasdev V, Bhakuni D, Narayanan K, Jain R. Intramedullary fat necrosis, polyarthritis and panniculitis with pancreatic tumor: a case report. Int J Rheum Dis 2010 Oct;13(4):e74-78. https://doi.org/10.1111/j.1756-185X.2010.01548.x

9. Narváez J, Bianchi MM, Santo P, de la Fuente D, Ríos-Rodriguez V, Bolao F, Narváez JA, Nolla JM. Pancreatitis, panniculitis, and polyarthritis. Semin Arthritis Rheum 2010 Apr;39(5):417423.

https://doi.org/10.1016/j.semarthrit.2008.10.001

10. Agarwal S, Sasi A, Ray A, Jadon RS, Vikram N. Pancreatitis panniculitis polyarthritis syndrome with multiple bone infarcts. QJM 2019 Jan 1;112(1):43-44. https://doi.org/10.1093/qjmed/hcy244

11. Obatake M, Yamane Y, Tokunaga T, Taura Y, Inamura Y, Nagayasu T. Arthralgia and osteolytic lesions associated with traumatic pancreatitis in a 10-year-old girl. Int J Pediatr 2009;950687. https://doi.org/10.1155/2009/950687

12. Lin CF, Chiu YM. Pancreatitis, panniculitis, and polyarthritis syndrome presenting with gouty arthritis: a case report. J Med Cases 2011;2(3):110-112. https://doi.org/10.4021/jmc178w

13. Shaikh MF, Mohamed A, Rosario H, Stratton RJ, Mangat P. When pancreatitis is not just pancreatitis. Rheumatology 2016 Apr;55(1):i65.

https://doi.org/10.1093/rheumatology/kew131.005

\section{CLINICAL CASE REPORT: PPP SYNDROME}

I.Vilčinskaitė, G.Srèbaliūtė, M.Garčauskis

Keywords: PPP syndrome, pancreatitis, panniculitis, polyarthritis, bone marrow necrosis, magnetic resonance imaging.

Summary

PPP syndrome is the complex of symptoms consisting of extrapancreatic manifestations of pancreatitis together with panniculitis, polyarthritis and bone marrow necrosis. The clinical case is presented in which patient having acute pancreatitis suffer from a rare complex of extrapancreatic symptoms - rash, followed by joint inflammation of ankle, wrist and knee along with bone marrow necrosis. The hypothesised pathology has been proved after the MRI. Conservative treatment of pancreatitis and symptomatic treatment with NSAIDs and glucocorticoids were not effective. Surgical treatment of pancreatic pseudocysts and lower femoral vein significantly improved the patient's condition and laboratory parameters returned to normal.

Correspondence to: vilcinskaite@yahoo.com

Gauta 2019-07-30 